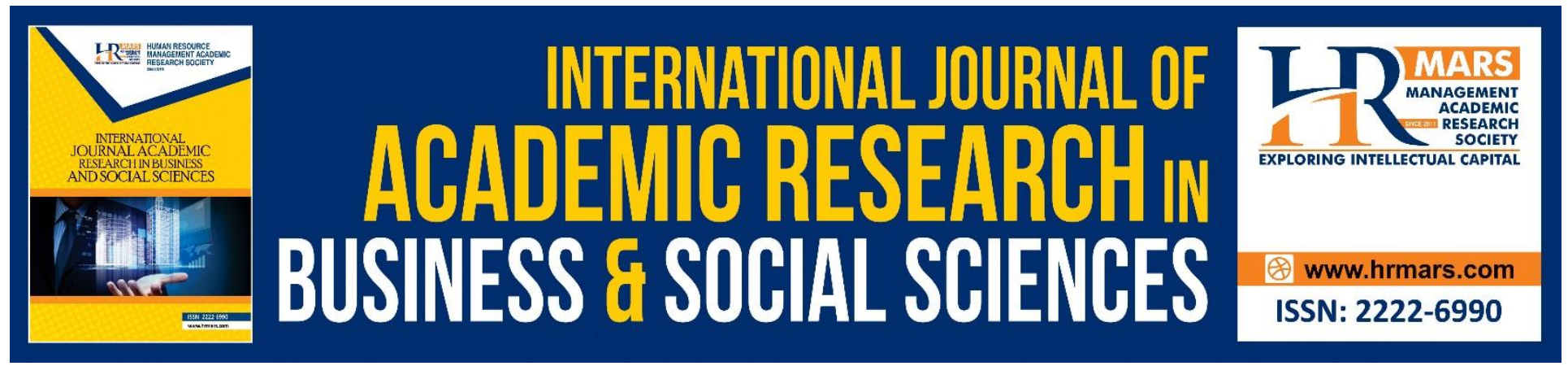

\title{
Does Psychological Capital Matter for the Public Sector Employees? A Survey of the Impact of Psychological Capital on Individual Job Performance in Malaysia
}

Nurul Ezaili Alias, Norfatiha Abu, Wei-Loon Koe, Najihah Hanisah Marmaya, Rozana Othman Noor Rafhati Romaiha

To Link this Article: http://dx.doi.org/10.6007/IJARBSS/v10-i8/7625 DOI:10.6007/IJARBSS/v10-i8/7625

Received: 18 May 2020, Revised: 19 June 2020, Accepted: 21 July 2020

Published Online: 28 August 2020

In-Text Citation: (Alias, Abu, Koe, Marmaya, \& Romaiha, 2020).

To Cite this Article: Alias, N. E., Abu, N., Koe, W-L., Marmaya, N. H., \& Romaiha, R. O. N. R. (2020). Does

Psychological Capital Matter for the Public Sector Employees? A Survey of the Impact of Psychological Capital on Individual Job Performance in Malaysia. International Journal Academic Research in Business and Social Sciences. 10(8), 772-787.

Copyright: (C) 2020 The Author(s)

Published by Human Resource Management Academic Research Society (www.hrmars.com)

This article is published under the Creative Commons Attribution (CC BY 4.0) license. Anyone may reproduce, distribute, translate and create derivative works of this article (for both commercial and non-commercial purposes), subject to full attribution to the original publication and authors. The full terms of this license may be seen at: http://creativecommons.org/licences/by/4.0/legalcode

Vol. 10, No. 8, 2020, Pg. 772 - 787

Full Terms \& Conditions of access and use can be found at http://hrmars.com/index.php/pages/detail/publication-ethics 


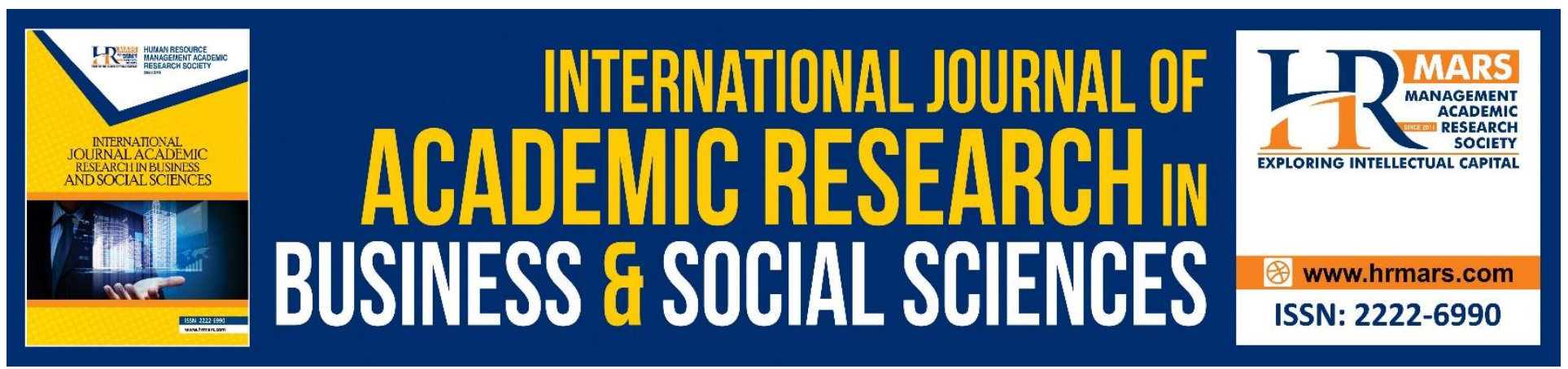

\title{
Does Psychological Capital Matter for the Public Sector Employees? A Survey of the Impact of Psychological Capital on Individual Job Performance in Malaysia
}

\author{
Nurul Ezaili Alias, Norfatiha Abu, Wei-Loon Koe, Najihah Hanisah \\ Marmaya, Rozana Othman Noor Rafhati Romaiha
}

Faculty of Business and Management, Universiti Teknologi MARA, Melaka City Campus, 75300

Melaka, Malaysia

\begin{abstract}
The Malaysian public has implemented various programs aid to improve the employee's performance and the attitude while carrying the task. However, the number of issues arise among public sector employees over the past year. It is including their involvement in personal businesses, high absenteeism, punctuality, and consequently distracted their focus and job performance. Thus, this led the study to investigate the most researched psychological capital construct and job performance study; psychological capital (self-efficacy, hope, resilience, and optimism) on job performance among individual employees in the Management Service Division of Public Service Department Malaysia. It used a self-administered questionnaire to collect data from 200 public sector employees in Malaysia. It developed a research model of psychological capital and job performance theory and concept. The conducted research analyses revealed that psychological capital significantly influenced job performance. As self-efficacy is the strongest predictor of job performance, it further proposed that it is essential for the public institutions and agencies to encourage high confidence level among their employees, and emphasizing the importance of having high self-efficacy in performing the job while serving the citizens directly and indirectly. Further, as public sector employers, the government needs to encourage its employees to be optimistic in performing their duties, whether the outcome is uncertain.
\end{abstract}

Keywords: Job Performance, Psychological Capital, Conservation of Resources (Cor) Theory, Employee, Public.

\section{Introduction}

The phenomenon of employee job performance has become an essential agenda by organizations nowadays. The reason for this is that job performance has a substantial contribution to the achievement of every individual performance standards, hence, the whole organizational performance. However, the challenge to ensure the consistency of every individual performance is 
INTERNATIONAL JOURNAL OF ACADEMIC RESEARCH IN BUSINESS AND SOCIAL SCIENCES Vol. 10, No. 8, 2020, E-ISSN: 2222-6990 @ 2020 HRMARS

at the optimum level becomes a never-ending agenda. Employee's level of job performance is not only based on the results but as well as the behaviours and traits. The reflections of their behaviours and traits in performing the tasks are closely related to the achievement of organizational goals and objectives (Campbell et al., 1990).

Evaluation of employee performance through the behaviours are the most popular and effective practice in the organizational performance management system. Thus, positive behaviours lead to better job performance level as compared to those who do not (Luthans \& Youssef, 2007). The concept of evaluating behaviours, other than results or traits, is not only on the individual but as well as on groups or teams. There are various factors of behaviours that affect individual job performance-it is from the factor of sociology, anthropology, science, and psychology to personal resources or psychological capital resources (Maher et al., 2017; Nasurdin et al., 2018).

As mentioned above, job performance is not only the primary agenda by organizations and practitioners but consequently becoming a direct and indirect interest among researchers (Tüzün et al., 2018). The study on the antecedents of job performance is becoming a continuous research agenda in order to close the field gaps. So, the process of transferring the study findings to the managers and practitioners' practice is continuously occurring. However, the definite antecedents of job performance have yet come into a reliable outcome. Kappagoda, Othman, \& Alwis (2014) argued that the vital factor to excellent job performance is employees' level of customer service, but in order to deliver a high ranking level of service to the customers is to examine the psychological capital state of every individual at the workplace. On the other hand, Saithong-in \& Ussahawanitchakit (2016) found that chronic stress, unstable emotional, and low career movement also influenced to low-level of job performance at the workplace.

One of the amongst top Malaysia's news press, Utusan Malaysia (2015), reported that public sector employees' job performance had become an issue to the government employer. The activities of involving in personal business, a high quota of absenteeism (over 200 days a year), and the issue of punctuality have distracted the job focus and performance. Due to this continuous problem, the Chief Secretary of Government, and Congress of Union of Employees in the Public and Civil Services (CUEPACS) Malaysia, has made a statement that proper action should be taken to those employees that are still showing the same performance problems after receiving proper courses to improve performance and career development. Thus, this official statement made by the government has confirmed that the issue of job performance among public sector employees is an important issue to be further researched, especially in the Malaysian context.

According to the American psychologist, Sheldon \& King (2001) indicated that 'employee's positive psychology' is the best predictor inside an employee to find out what will work, what is right, and what can be improving. Psychologically, there four main elements of positive psychological capital, self-efficacy (confidence), hope (perseverance toward the goals), optimism (positive attribution), and resilience (strong, sturdy, and readiness) (Luthans \& Youssef, 2004, 2007; YoussefMorgan \& Luthans, 2015). The study of psychological capital influence job performance has extensively been conducted in both public and private sectors, as such in accounting, university, banking, police department, hotel, tourism, and other various industries (Abbas et al., 2014; Kappagoda et al., 2014; Saithong-in \& Ussahawanitchakit, 2016; Tüzün et al., 2018). However, based on previous literature, it was found that most of the studies were conducted in private sectors, Egypt, Brazil, Turkey, South Korea, India, and Pakistan (Abbas et al., 2014; Choi \& Lee, 2014; Kappagoda et 
al., 2014; Maher et al., 2017; Polatci \& Akdogan, 2014; Santos et al., 2018; Tüzün et al., 2018). A lack number of studies is found in the public sector, specifically in Malaysia (Mohd Nasurdin et al., 2018).

In conclusion, Malaysia's public sector employees also cannot be exempted from the issue of job performance, especially when this sector is the fundamental role to increase the citizens' satisfaction and well-being. Thus, this study intended to close the study setting gap by conducting in the public sector. Therefore, this study examined the influence of psychological capital (self-efficacy, hope, optimism, and resilience) on job performance, specifically in the Management Service Division of Public Service Department (PSD), Malaysia. The objectives of the study:

1. To identify the relationship between self-efficacy and job performance in the Management Service Division of Public Service Department (PSD), Malaysia.

2. To identify the relationship between hope and job performance in the Management Service Division of Public Service Department (PSD), Malaysia.

3. To identify the relationship between resiliency and job performance in the Management Service Division of Public Service Department (PSD), Malaysia.

4. To identify the relationship between optimism and job performance in the Management Service Division of Public Service Department (PSD), Malaysia.

5. To identify the most significant factor to job performance in the Management Service Division of Public Service Department (PSD), Malaysia.

\section{Literature Review}

Job Performance

Job performance has been extensively researched by previous researchers in organizational behaviour and human resource management academic literature (Borman \& Motowidlo, 1993). The term of job performance initially defined by Murphy (1989), as the work of someone that focuses on the behaviour than the outcome or result, because if managers focus on evaluating the result, the staff will find the easiest way to achieve it. In the 1990s, Campbell, McCloy, Oppler, \& Sager (1993) described that job performance is an observable of employees' behaviour that involved in the actual work. Further, Campbell et al. (1990) defined job performance as not only an identifiable behaviour that an individual engages in their tasks and duties, but it also has an evaluative aspect. Moreover, Motowidlo, Borman, \& Schmit (1997) described job performance as the behaviours or activity oriented to the achievement of corporate goals and objectives. Besides, previous researchers suggested job performance as a multi-factor construct, indicate how well an individual performs their tasks or how individuals manage the available resources to perform the tasks (Boshoff \& Arnolds, 1995; Roodt \& La Grange, 2001).

As mentioned above, traditionally, job performance as an evaluative behaviour that employees carry out the tasks or execute and complete the well-defined tasks (Borman \& Motowidlo, 1993). However, the continuous change in today's nature of work and organizations has challenged the traditional perspective of job performance. Then, Borman \& Motowidlo (1993) identified two classifications of job performance that can be explored; role performance (directly related to tasks and duties) and extra role performance (indirectly related to tasks and duties but related to organizational outcomes). Further, the researchers asserted role performance as "task performance" and extra role performance as "contextual performance."

Hogan \& Holland (2003) explained that task performance corresponds to getting ahead, while contextual performance corresponds to getting along with others. In other definition of the terms 
INTERNATIONAL JOURNAL OF ACADEMIC RESEARCH IN BUSINESS AND SOCIAL SCIENCES Vol. 10, No. 8, 2020, E-ISSN: 2222-6990 @ 2020 HRMARS

are, task performance as the aspects of the procedure of performance - the application of mechanical skills and knowledge to perform a task, while, contextual performance as actions that support the managerial, psychological and social context in which task is performed such as volunteering for extra activities and helping others. Thus, this description justified the definition of job performance in this study.

Research has found that antecedents of job performance, which are job satisfaction, organizational citizenship behaviour, and work engagement have proven to promote positive behaviour of job performance (Alessandri et al., 2018; Jung \& Yoon, 2015; Mohd Nasurdin et al., 2018). However, it is still a lack of studies concentrated on individual psychological capital and job performance, especially among public sector employees (Polatci \& Akdogan, 2014; Saithong-in \& Ussahawanitchakit, 2016). In other words, the relationship between psychological capital elements, which are self-efficacy, hope, optimism, and resilience, to create a high level of job performance has not been fully explored, especially in the local setting. Hence, literature found it is still a scarcity of studies that investigated psychological capital and job performance at the individual level, and studies researched on psychological capital and job performance among public sector employees are still limited.

\section{Relationship between Psychological Capital Dimensions and Job Performance}

Psychological capital is a new extension in the study of positive organizational behaviour. The model comprises of four elements that are malleable and can explain an individual's resources or capacities to influence positive organizational behaviours (Luthans, 2002). The four elements of psychological capital resource capacities are self-efficacy, hope, optimism, and resilience (Luthans et al., 2004). These are only four elements of psychological capital construct that are stringent criteria set for being positive organizational behaviour. Luthans \& Youssef $(2007$, p. 3) defined psychological capital construct as "an individual's positive psychological state of development." The researchers theorized that during psychological state development, individuals are characterized by the level of their selfefficacy, optimism, hope, and resilience.

The concept of psychological capital is based on a theory by Hobfoll (1989). He theorized the relationships between personal characteristics and job outcomes in theory called the conservation of resources (COR). He posited that a person has to attain the resources to differentiate their action with one another person. The resources could be their personality traits, characteristics, forces, situations, objects, so forth. Such resources are then defined as "[...] those entities that either are centrally valued in their own right, or act as means to obtain centrally valued ends" (Hobfoll, 2002, p. 307). Later, Wright \& Hobfoll (2004) identified four elements of personal resources, which are selfefficacy, hope, optimism, and resilience, that fall under the constructs of COR theory. These four personal resources are valued and can be measured in an individual employee's psychological capital and considered as necessary to organizations (Avey et al., 2010; Kim et al., 2017). Employees not only performed their duties to achieve their goals and objectives but in order to perform at their optimum level is always to be motivated to acquire and foster their valued personal resources (psychological capital) to sustain excellent job performance continuously. Employees who managed to acquire high self-efficacy, hope, optimism, and resilience are believed to have resource caravan. Consequently, they will continue satisfying the tasks, duties, responsibilities, work relations, and environment (Alessandri et al., 2018; Peterson et al., 2011). 
INTERNATIONAL JOURNAL OF ACADEMIC RESEARCH IN BUSINESS AND SOCIAL SCIENCES Vol. 10, No. 8, 2020, E-ISSN: 2222-6990 @ 2020 HRMARS

In possessing positive psychological capacities, an individual that is having the confidence to take on and put in the necessary effort to succeed (self-efficacy); being perseverant toward achieving goals and, when necessary, redirecting their paths toward goals in order to succeed (hope); willing to have a positive expectation about succeeding now and in the future (optimistic); and being able to endure and bounce back from adversity to attain success (resilience). Thus, based on the theory and past researches, individuals who score higher in psychological capital can be expected to put extra effort and perseverance based on greater confidence (efficacy), more willpower, and energy to generate multiple solutions to problems or goal blockages (hope); will be more likely to voice out positive expectations about results (optimism); and will respond more positively to adversity and setbacks (resilience). In other words, the higher an individual's psychological capital comprising efficacy, hope, optimism, and resilience, the higher the level of job performance.

Polatci \& Akdogan (2014) determined that the most significant factor of job performance is psychological capital. The variables of job performance and psychological capital have a significant relationship. They argued that employees with high psychological capital are more likely to endure and enhance positive performance, to fulfill not only the customers' but also their colleagues' expectations. Further, employees in positive psychological capital are always expecting a high level of job performance to attain high-performance standards. Consequently, if they continue working in a positive psychological environment, they are not only performing at their best of individual performance but to both internal and external organization's stakeholders.

Recently, Santos, Reis Neto, \& Verwaal (2018) tested the relationship between psychological capital and job performance in the case of 369 public and private sector employees in Brazil, and the relationship was significant. In another study by Maher, Mahmoud, \& Hefny (2017), an exploratory study focused on the impact of psychological capital on Egyptian employees' work well being. The analysis was using in-depth interviews with three senior employees and leaders in different public organizations. It revealed that leaders of public organizations should pay more attention to the importance of positive psychological resources as core psychological factors that affect their employees' performance and work well being. Besides, in a recent study by (Ullah Khan et al., 2017), have examined the relationship between psychological capital and employee performance on 170 employees in public sector universities of Peshawar, and the relationship was significantly associated. Studies on psychological capital influenced job performance among employees have been explored dynamically in previous researches.

In the extant literature, the study on job performance in the workplace has attracted the interest of many researchers, including Asian researchers (Choi \& Lee, 2014; Hon et al., 2013; Saithong-in \& Ussahawanitchakit, 2016). However, several important aspects have also been overlooked by the existing literature. For instance, psychological capital aspects influence an individual's job performance in the public sector have not been sufficiently taken into account by existing studies (Maher et al., 2017; Saithong-in \& Ussahawanitchakit, 2016; Santos et al., 2018; Ullah Khan et al., 2017), and specifically, studies conducted on the local setting are still scarce (Mohd Nasurdin et al., 2018).

\section{Self-Efficacy}

The concept of self-efficacy is based initially on the social cognitive theory by Bandura (1986). He defined self-efficacy as a person's sense in assessing his or her ability to respond to a given event. If he or she believes there is no ability to do anything to gain success, he or she instead feel fear and 
INTERNATIONAL JOURNAL OF ACADEMIC RESEARCH IN BUSINESS AND SOCIAL SCIENCES Vol. 10, No. 8, 2020, E-ISSN: 2222-6990 @ 2020 HRMARS

try to escape from the event. However, is the ability is vice versa, he or she will try to face the event and complete it enthusiastically. Stajkovic \& Luthans (1998) conceptualized self-efficacy as the first element in psychological capital, and defined it as a person's confidence in her or his abilities to create readiness, motivation, and find ways to work as harder to succeed. They argued that the element of self-efficacy is suitable to be applied to a specific task or to focus on a given incident or event. For instance, an individual considers the uniqueness of the situation, evaluates the probability of his or her actions to gain success, and then engages to some action(s) based on his or her perceived degree of self-efficacy. In a very practical sense, one might simply estimate his or her degree of confidence to succeed in a particular situation, considering the internal or external factor(s).

Luthans (2002) matched the element of self-efficacy to all positive organizational behaviour criteria. He defined self-efficacy as an individual employee's confidence in their ability to complete the tasks or duties. Thus, there is a desire to make or do difficult or challenging things. The higher the self-efficacy in an individual employee, the higher the effort he or she will put into completing the tasks and achieve the goals. This element of self-efficacy has been diversely exploited in academic research and work practice. Previous studies have researched and significantly found the effect of self-efficacy on job performance (Jung \& Yoon, 2015; Polatci \& Akdogan, 2014; Saithong-in \& Ussahawanitchakit, 2016; Santos et al., 2018).

\section{Hope}

Hope can be described as a positive state of mind to tolerate the work progress to achieve success. Hope differs individually based on goals, objectives, plans, and encouragements a person has. It is the second element of psychological capital (Snyder et al., 1991). Hope is portraying a person's thoughts about how he or she discovers avenues to achieve the goals. Also, Snyder (2000) has included in agency and pathway components. Agency is goal-directed energy and the pathway to achieving the goals. He also defined hope consists of both the willpower (agency) and way power (pathways) that a person has to reach a goal. Agency is the willpower to achieve the desired goal, and pathways involve identification of alternative ways or contingency plans after a person has forecast the potential obstacles to reach the desired goal (Snyder, 2000; Snyder et al., 1996). Likewise, Luthans, Avolio, Avey, \& Norman (2007) described hope as a person who keeps moving forward positively and moves up the efforts after facing some obstacles to achieve the desire goals and objectives. In this research, they have used hope in the organizational behaviour field study and defined it as ideas or beliefs of a person to focus on the tasks where he or she believes that able to find ways to achieve the goals with the motivation and intended to follow it.

Hope is seen as a cognitive process accompanied by realistic behaviours to achieve the goals, and this process involves the relationships between desire, behaviours, and goals. Bryant \& Cvengros (2004) have stood the arguments on the similarity between hope and optimism by demonstrating both elements to be empirically and theoretically distinct elements. They have revealed that each of the elements played a different significant role in the construct and job performance. Further, Peterson \& Byron (2008) asserted that employees with high hope would ensure the desired goals are achieved with extraordinary individual efforts and ability and move forward through any unexpected hurdles. With the astonishing ability, it will lead the employees with more alternative ideas and constructive actions to goals accomplishment. They found that the higher the level of hope, the higher the level of job performance, even after controlling their self-efficacy. Previous studies have researched the relationship between hope and job performance, and the relationship was found to 
INTERNATIONAL JOURNAL OF ACADEMIC RESEARCH IN BUSINESS AND SOCIAL SCIENCES Vol. 10, No. 8, 2020, E-ISSN: 2222-6990 @ 2020 HRMARS

be significant (Abbas et al., 2014; Saithong-in \& Ussahawanitchakit, 2016; Youssef-Morgan \& Luthans, 2015).

\section{Optimism}

Optimism is the third element of psychological capital, which generally explained as a person who always expects something good to happen while pessimism is the opposite of optimism, in which a person who always expect bad things to happen (Carver et al., 2005). Tiger (1979) has defined optimism as the mood or attitude that is associated with social expectations or importance in the future. According to Carifio \& Rhodes (2002), optimism represents the strength of the internal locus of control of a person. The stronger the internal locus of control, the higher the degree of enthusiasm of a person to achieve success in the present or future in any circumstance. It is also when a person believes the outcome is attainable, and optimism will take the lead to actual performance. Luthans et al. (2007) defined optimism as the power of positive thinking. It is a feature of the rationalism and positive perception toward expectation. Recognition of mistakes causes the result to be learned. The optimistic people believe that success is achieved from the efforts that have been put in the present or future. Luthans et al. (2007) also argued optimism differed from hope because there is no room to be optimistic while a person still being hopeful.

Being prepared for any circumstance is where a person can better understand what optimism is. Optimism also can prevent an individual from being too passive, not participative, do not have guts in giving or sharing an opinion, and be a person who always initiates a positive attribution (optimism) about succeeding now and in the future (Youssef-Morgan \& Luthans, 2015). Previous studies have found that optimism has a significant relationship with job performance (Ramphal, 2016; Saithong-in \& Ussahawanitchakit, 2016).

\section{Resilience}

This element of psychological capital is related to how a person adapts him or herself to failures and recover from it immediately. It is showing an adaptability system of a person and the recovery process toward facing adversity or risk. Optimism is the fourth element of the psychological capital construct (Masten \& Reed, 2002). In the organizational behaviour field of study, resilience as a positive psychological ability to recover from difficulties at the workplace. The difficulties can be described by any conflict, failure, instability, or unfavoured events (Luthans, 2002). From this, it can be concluded that resilience is a positive force that an employee should attain when facing hardships at the workplace. It is believed that all individual employees cannot escape from any setbacks or unfavoured conditions in their career stage. Not to mention, reality vs expectation matters to anybody. Resilience represents how a person's ability to rebuilt and regain strength to ensure the desired goal is achieved (Bonanno, 2005).

Similarly to Maddi's (2005) work on hardiness, noted that employees who continue the high momentum and experience a condition such as "little or no loss of functioning" after facing significant setbacks have a high level of resilience. He further notes, in order to attain high resiliency, hardiness is the key. Likewise, he stated: "enhances resilience in a wide range of stressful circumstances." Resilience differs from Maddi's work on hardiness, as resilience is argued to be more applicable to enhance job performance during heavy workloads or job burdens. When adversity takes into place, resilience plays a significant role to limit or eliminate the loss functioning moment from escalating too long. It leads employees to "bounce back" to the goal achievement. Previous researchers have 
INTERNATIONAL JOURNAL OF ACADEMIC RESEARCH IN BUSINESS AND SOCIAL SCIENCES Vol. 10, No. 8, 2020, E-ISSN: 2222-6990 (C) 2020 HRMARS

found that there is a significant relationship between resilience and job performance (Kaplan \& Biçkes, 2013; Saithong-in \& Ussahawanitchakit, 2016; Youssef-Morgan \& Luthans, 2015).

\section{Research Model and Hypotheses}

Discussion in the previous section highlighted that psychological capital construct comprised of four elements; self-efficacy, hope, optimism, and resilience. All independent variables are deemed to have a significant influence on job performance. As such, Fig. 1 shows the research model.

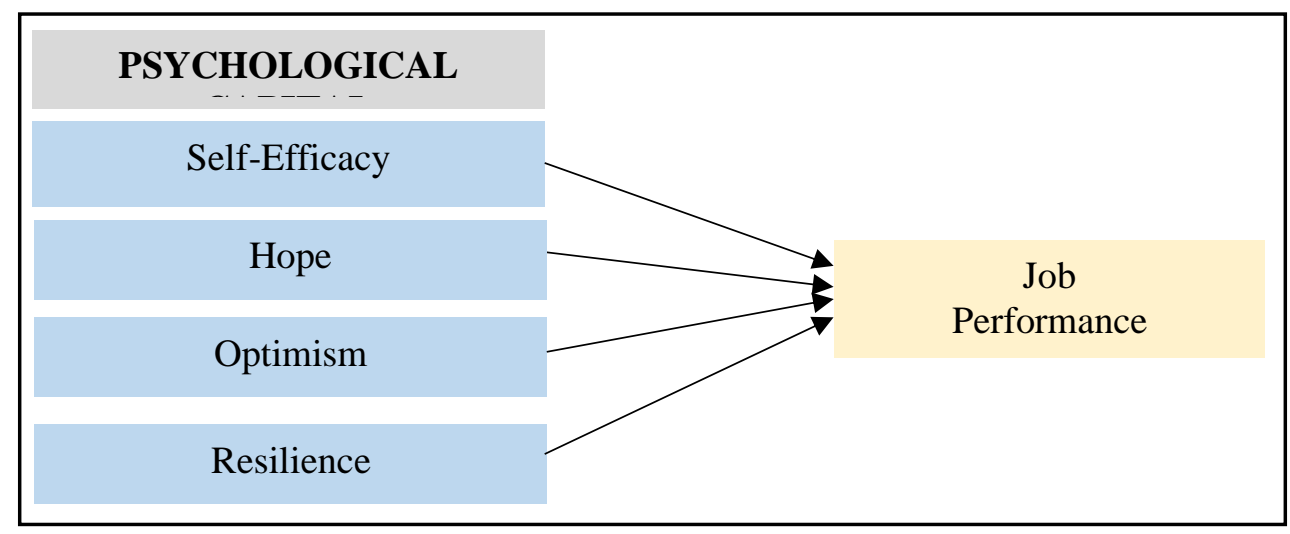

Figure 1. Research model

This study has also developed the following hypotheses to guide the study:

$\mathrm{H}_{1}$ : There is a significant relationship between self-efficacy and job performance.

$\mathrm{H}_{2}$ : There is a significant relationship between hope and job performance.

$\mathrm{H}_{3}$ : There is a significant relationship between optimism and job performance.

$\mathrm{H}_{4}$ : There is a significant relationship between resilience and job performance.

\section{Methodology}

\section{Research Design}

This study examined the impact of psychological capital (self-efficacy, hope, optimism, and resilience) on public sector employees' job performance. Since this study aimed at testing the relationships between predictors and consequence, and all variables were measurable, this study implemented a quantitative research method. Specifically, this study employed a questionnaire survey method to collect the desired data from the respondents. The unit of analysis in this study was among individual public sector employees-all permanent employees employed in the Management Service Division of Public Service Department (PSD) Malaysia. Public Service Department (PSD) Malaysia is the third and latest Federal Territory, located in west-central Peninsular Malaysia. Since the selected department has multiple divisions, this study selected the only division that is approachable by the researchers.

However, the selected division is among the largest division with a large number of employees, and it also caters to all permanent employees only. Hence, this leads to the justification of the selection of the division. As for sample selection, since the PSD kept its employee data as confidential, this study conducted a convenient sampling technique to collect the data. Not to mention that the selected division is included in the three largest divisions in PSD. Thus, it can be considered as sufficient to provide findings that represent the whole department. A total of 200 
INTERNATIONAL JOURNAL OF ACADEMIC RESEARCH IN BUSINESS AND SOCIAL SCIENCES Vol. 10, No. 8, 2020, E-ISSN: 2222-6990 @ 2020 HRMARS

usable and valid responses were collected from 250 questionnaires that have been distributed throughout the division.

\section{Research Instrument}

As mentioned in the previous section, this study employed a questionnaire survey method. Therefore, the respondents were asked to indicate their responses to self-administered questionnaires. The questionnaire consists of three main sections, and altogether there were 45 questions. In order to provide the reliability and validity of data findings, the measurement items in this study were adopted and adapted from previous studies. The first section was the background of the respondent with five items. The second section was job performance with sixteen items (Kappagoda et al., 2014). Lastly, the third section was psychological capital, six items for self-efficacy, six items for hope, six items for optimism, and six items for resilience (Jung \& Yoon, 2015; Kappagoda et al., 2014).

The researchers have slightly modified the questions to suit the cultural background of respondents. Since the type of questions in this study were closed-questions, so the respondents were asked to indicate their level of agreeableness or disagreeableness based on a five-point Likert scale ( $1=$ strongly disagree to $5=$ strongly agree). A pilot test has also employed in order to determine errors in questionnaires and reliability of inter-items. Then, an improvised version of questionnaires has been made from the feedback received by the respondents. Hence, the initial reliability analysis revealed that all items achieved internal consistency with Cronbach's alphas above 0.70 (Pallant, 2011).

\section{Results and Discussion \\ Descriptive Statistics}

A total of 200 usable responses were collected from 250 sets of questionnaires distributed and yielded to $80.0 \%$ of the response rate. The permanent employees who responded to the questionnaire were mostly female $(58.0 \% ; n=116)$. It was found that $65.5 \%(n=131)$ of them were age between $31-40$ years old and followed by $23.5 \%(n=47)$ of them were age below 30 years old. The majority of them were married $(77.0 \% ; n=154)$, and the remaining were still single $(23.0 \% ; n=46)$. Besides, almost half of them have served the PSD between $6-10$ years ( $46.5 \% ; n=93$ ) and followed by $31.5 \%(n=63)$ of them have the service tenure 11 years and above. For education background, about $51.0 \%(n=102)$ of them possessed a diploma, followed by $21.50 \%(n=43)$ of them were among bachelor's degree holder, $19.0 \%(n=38)$ of them are secondary school graduates (SPM), 5.0\% $(n=10)$ with master's degree, and $3.5 \%(n=7)$ of them have a PhD.

\section{Reliability, Mean and Pearson Correlation Analysis}

Research that uses questionnaires as the instrument to collect data has to determine the internal consistency of the measurement items for each variable. Thus, as presented in Table 1, the Cronbach's alpha coefficient $(\alpha)$ for all variable items were between $(0.74<\alpha<0.96)$, and this $\alpha$ value range is considered as reliable because it is above the threshold of 0.70 . Table 1 also shows the mean value for each variable, and self-efficacy obtained the highest mean value $(m=4.24)$, followed by job performance $(m=4.08)$, hope $(m=4.06)$, optimism $(m=3.99)$, resilience reported as the lowest $(m=3.72)$. It can be summarized that most of the respondents were agreed with all the statements in the questionnaire. 
INTERNATIONAL JOURNAL OF ACADEMIC RESEARCH IN BUSINESS AND SOCIAL SCIENCES Vol. 10, No. 8, 2020, E-ISSN: 2222-6990 @ 2020 HRMARS

The research also performed a Pearson Correlation coefficients analysis to determine the degree of association between pairs of variables. Table 1 illustrated that the coefficient value of all pairs of variables was between moderate to strong strength of association and positively correlated with each other (Uma Sekaran \& Bougie, 2013). Statistically revealed that the pair of self-efficacy and job performance reported as the highest correlation coefficient $(r=0.76 ; p<0.01)$, followed by hope and job performance $(r=0.75 ; p<0.01)$, optimism and job performance $(r=0.71 ; p<0.01)$, while the lowest correlation coefficient value was between resilience and job performance $(r=0.57 ; p<0.01)$. Since the range of $r$-value was below 0.90 , where the two predictors were not correlated very strongly; therefore, there is no multicollinearity issue in this research (Meyers et al., 2006). The reported of the non-existence of the multicollinearity issue confirmed that regression analysis could further proceed in this study.

Table 1. Descriptive and correlation analysis

\begin{tabular}{lllllllll}
\hline & $\boldsymbol{\alpha}$ & $\mathbf{m}$ & $\mathbf{s d}$ & $\begin{array}{l}\text { Self- } \\
\text { efficacy }\end{array}$ & Hope & Optimism & Resilience $\begin{array}{l}\text { Job } \\
\text { Performance }\end{array}$ \\
\hline Self-efficacy & 0.88 & 4.24 & 0.45 & 1 & & & \\
Hope & 0.88 & 4.06 & 0.46 & $0.83^{* *}$ & 1 & & \\
Optimism & 0.74 & 3.99 & 0.49 & $0.63^{* *}$ & $0.71^{* *}$ & 1 & & \\
Resilience & 0.78 & 3.72 & 0.56 & $0.69^{* *}$ & $0.73^{* *}$ & $0.74^{* *}$ & 1 & \\
Job & 0.96 & 4.08 & 0.50 & $0.76^{* *}$ & $0.75^{* *}$ & $0.71^{* *}$ & $0.57^{* *}$ & 1 \\
Performance & & & & & & & & \\
\hline
\end{tabular}

** Significant at $<0.01$

\section{Multiple Regression Analysis}

Four hypotheses were developed in this study, and the hypotheses were tested using multiple regression analysis because it was appropriate in examining the significant relationship between variables, independent variables, and dependent variable. As stated by Meyers et al. (2006) and Cohen (1968), a VIF value of $(<10)$ is associated with a tolerance of $(>0.1)$ and is considered the data also did not have any multicollinearity issues. As presented in Table 2, there is no multicollinearity issue; thus, multiple regression analysis was deemed to be suitable in this study.

Table 2 reported that the research model of this study was statistically significant because the F-statistics value is statistically significant $(F=113.82 ; p<0.001)$. Based on the $R$-squared obtained $\left(R^{2}=0.70\right)$, it represents $70 \%$ of the variations in job performance was explained by four predictors of psychological capital elements (self-efficacy, hope, optimism, and resilience). Statistically reported, all of the predictors, self-efficacy $(\beta=0.46$; sig. $=0.00)$, hope $(\beta=0.27$; sig. $=0.00)$, optimism $(\beta=0.43$; sig.=0.00), and resilience $(\beta=-0.23$; sig. $=0.00)$ were found to have a significant relationship with job performance. Self-efficacy is found as the most significant factor, followed by optimism. Therefore, the results confirmed to support the $\mathrm{H}_{1}, \mathrm{H}_{2}, \mathrm{H}_{3}$, and $\mathrm{H}_{4}$ of the study. 
INTERNATIONAL JOURNAL OF ACADEMIC RESEARCH IN BUSINESS AND SOCIAL SCIENCES Vol. 10, No. 8, 2020, E-ISSN: 2222-6990 @ 2020 HRMARS

Table 2. Multiple regressions analysis

\begin{tabular}{llllll}
\hline Variables & Std. $\boldsymbol{\beta}$ & T-value & Sig. & VIF & Tolerance \\
\hline Self-efficacy & 0.46 & 5.89 & 0.00 & 0.28 & 3.54 \\
Hope & 0.27 & 3.14 & 0.00 & 0.23 & 4.31 \\
Optimism & 0.43 & 6.84 & 0.00 & 0.35 & 2.83 \\
Resilience & -0.23 & -3.55 & 0.00 & 0.38 & 2.59 \\
\hline F-statistics & 113.82 (sig. <0.01) & & & \\
R-squared & 0.70 & & & & \\
\hline
\end{tabular}

Dependent variable: Job performance

\section{Discussion}

Based on the revealed findings, the influence of self-efficacy on job performance was significant. The results obtained supported the previous findings by (Jung \& Yoon, 2015; Polatci \& Akdogan, 2014; Saithong-in \& Ussahawanitchakit, 2016). Self-efficacy plays a significant role in increasing the level of job performance. With high self-efficacy, it assists the employees in the achievement of goals in a working environment. This finding also has been tested previously in any sector, such as public, private, hotel, tourism, customer service, and accounting (Jung \& Yoon, 2015; Polatci \& Akdogan, 2014; Saithong-in \& Ussahawanitchakit, 2016; Santos et al., 2018). It is believed that an employee with high self-efficacy owns their capabilities and confidence level in solving the problem at the workplace. It is also able to motivate a person to participate in discussions actively or share their opinion toward any discussion or decision-making process.

In addition, this study also supported that hope significantly influenced job performance. With higher hope, employees are more likely influence to have positive job enthusiasm, job commitment, and job performance. Consequently, it will also influence the employees to have a high impact on job performance by generating alternative pathways and new ideas to innovate the approach to complete tasks in the workplace (Abbas et al., 2014; Saithong-in \& Ussahawanitchakit, 2016; YoussefMorgan \& Luthans, 2015). Hope is persevering toward goals and, when necessary, it redirects the paths to goals (hope) in order to succeed. Also, it is believed that hope as the belief that gives motivation and ability of a person to perform the job at their best ability at the workplace.

The results of this study also revealed that optimism has a significant relationship with job performance. Thus, this supports the previous studies by (Ramphal, 2016; Saithong-in \& Ussahawanitchakit, 2016). Optimism is a way to give a reason or a psychological state of mind to clarify the situation in the right way, with the expectation that there will be good results in their work. Optimism is also an essential element for a salesperson to face any adverse or challenging situations that could potentially have a positive impact on work-related goals. It is believed optimism as the guts to face challenges and being enthusiastic in every immediate and future event that an employee is facing. Even, the plan has not turned as expected; an employee will still keep trying to perform better in their next move with looking to more bright sight in their career.

Finally, the study findings revealed the significant influence of resilience on job performance. Resilience is the ability to endure or adjust mood quickly to normal when an employee faced with uncertainty, conflict, and failure in performing the job to achieve desired goals (Saithong-in \& 
INTERNATIONAL JOURNAL OF ACADEMIC RESEARCH IN BUSINESS AND SOCIAL SCIENCES Vol. 10, No. 8, 2020, E-ISSN: 2222-6990 @ 2020 HRMARS

Ussahawanitchakit, 2016). Kaplan \& Biçkes (2013) observed employees with high capabilities are wisely cope with the pressure or stress situation, or in other words, those with excellent resilience were satisfied with their tasks and performed better in their organization. Moreover, when employees surrounded by problems and adversity, with high resilience, they will sustain and bounce back and even beyond (resilience) to attain success (Youssef-Morgan \& Luthans, 2015). Besides, the ability to quickly adjust the negative mood to normal and resilience is believed as the capability and strength that employees are facing in a critical and uncertain situation.

\section{Conclusion}

The study was conducted to examine the psychological capital elements influencing job performance among public sector employees in Malaysia. The findings of the study revealed that all independent variables of the study, self-efficacy, hope, optimism, and resilience significantly influenced job performance. This can be described that psychological capital is essential in creating positive organizational behaviour mainly on their job performance, especially in the public sector. So, by having positive psychological capital, employees will always keep enhancing their job performance level in any uncertain event or circumstance. The findings revealed that the psychological capital construct can inevitably have a significant impact on job performance, specifically in the local context of this study and among public sector employees.

Scholarly, this study closed the gaps in examining the relationships between psychological capital construct and job performance as the existing literature provided a lack of findings, specifically among public sector employees in Malaysia. This study enriched the extant literature by combining the COR theory to determine employees' job performance. Practically, this study also contributed to the body of knowledge in investigating the important role of psychological capital construct on individual employees in encouraging better job performance among public sector employees. It follows the COR theory, where employees have to be motivated to acquire and foster their valued personal resources (psychological capital) in order to sustain excellent job performance continuously. Employees who strived to increase or to attain self-efficacy, hope, optimism, and resilience are believed to have great personal resources than others. As a result of this acquisition, it will continue to impact their motivation and performance.

The limitations of the study cannot be ignored. For instance, this study only focused on public sector employees. Due to a lack of previous findings between psychological capital construct and public sector employee's job performance, this study investigated these four elements in psychological capital on public sector employees in Malaysia, especially in today's uncertain and challenging work environment. Therefore, future researchers are suggested to include other departments in federal territory, Malaysia, and future studies are recommended to include other personal resources or capital of job performance, such as cultural and social capital.

\section{Acknowledgments}

This study was supported by publication funds under Universiti Teknologi MARA, Melaka, Malaysia.

\section{References}

Abbas, M., Raja, U., Darr, W., \& Bouckenooghe, D. (2014). Combined Effects of Perceived Politics and Psychological Capital on Job Satisfaction, Turnover Intentions, and Performance. Journal of Management. https://doi.org/10.1177/0149206312455243 
INTERNATIONAL JOURNAL OF ACADEMIC RESEARCH IN BUSINESS AND SOCIAL SCIENCES Vol. 10, No. 8, 2020, E-ISSN: 2222-6990 @ 2020 HRMARS

Alessandri, G., Consiglio, C., Luthans, F., \& Borgogni, L. (2018). Testing a dynamic model of the impact of psychological capital on work engagement and job performance. Career Development International, 23(1), 33-47. https://doi.org/10.1108/CDI-11-2016-0210

Avey, J. B., Nimnicht, J. L., \& Pigeon, G. N. (2010). Two field studies examining the association between positive psychological capital and employee performance. Leadership \& Organization Development Journal. https://doi.org/10.1108/01437731011056425

Bandura, A. (1986). Social foundations of thought and action : a social cognitive theory / Albert Bandura. New Jersey: Prentice-Hall, 1986.

Bonanno, G. A. (2005). Clarifying and extending the construct of adult resilience. American Psychologist. https://doi.org/10.1037/0003-066X.60.3.265b

Borman, W. C., \& Motowidlo, S. J. (1993). Expanding the criterion domain to include elements of contextual performance. In Personnel Selection in Organizations.

Boshoff, C., \& Arnolds, C. (1995). Some antecedents of employee commitment and their influence on job performance: A multi foci study. South African Journal of Business Management. https://doi.org/10.4102/sajbm.v26i4.832

Bryant, F. B., \& Cvengros, J. A. (2004). Distinguishing hope and optimism: Two sides of a coin, or two separate coins? Journal of Social and Clinical Psychology. https://doi.org/10.1521/jscp.23.2.273.31018

Campbell, J. P., McCloy, R. A., Oppler, S. H., \& Sager, C. E. (1993). A theory of performance. Personnel Selection In Organizations.

Campbell, J. P., Mchenry, J. J., \& Wise, L. L. (1990). Modeling Job Performance In A Population Of Jobs. Personnel Psychology. https://doi.org/10.1111/j.1744-6570.1990.tb01561.x

Carifio, J., \& Rhodes, L. (2002). Construct validities and the empirical relationships between optimism, hope, self-efficacy, and locus of control. Work.

Carver, C. S., Smith, R. G., Antoni, M. H., Petronis, V. M., Weiss, S., \& Derhagopian, R. P. (2005). Optimistic personality and psychosocial well-being during treatment predict psychosocial wellbeing among long-term survivors of breast cancer. Health Psychology. https://doi.org/10.1037/0278-6133.24.5.508

Choi, Y., \& Lee, D. (2014). Psychological capital, Big Five traits, and employee outcomes. Journal of Managerial Psychology. https://doi.org/10.1108/JMP-06-2012-0193

Cohen, J. (1968). Multiple regression as a general data-analytic system. Psychological Bulletin. https://doi.org/10.1037/h0026714

Hobfoll, S. E. (1989). Conservation of Resources: A New Attempt at Conceptualizing Stress. American Psychologist. https://doi.org/10.1037/0003-066X.44.3.513

Hobfoll, S. E. (2002). Social and Psychological Resources and Adaptation. Review of General Psychology. https://doi.org/10.1037/1089-2680.6.4.307

Hogan, J., \& Holland, B. (2003). Using theory to evaluate personality and job-performance relations: A socioanalytic perspective. Journal of Applied Psychology. https://doi.org/10.1037/00219010.88.1.100

Hon, A. H. Y., Chan, W. W. H., \& Lu, L. (2013). Overcoming work-related stress and promoting employee creativity in hotel industry: The role of task feedback from supervisor. International Journal of Hospitality Management. https://doi.org/10.1016/j.ijhm.2012.11.001

Jung, H. S., \& Yoon, H. H. (2015). The impact of employees' positive psychological capital on job satisfaction and organizational citizenship behaviors in the hotel. International Journal of 
INTERNATIONAL JOURNAL OF ACADEMIC RESEARCH IN BUSINESS AND SOCIAL SCIENCES

Vol. 10, No. 8, 2020, E-ISSN: 2222-6990 @ 2020 HRMARS

Contemporary Hospitality Management, 27(6), 1135-1156. https://doi.org/10.1108/IJCHM-012014-0019

Kaplan, M., \& Biçkes, D. M. (2013). The relationship between psychological capital and job satisfaction: A study of hotel businesses in Nevşehir. Journal of Personality.

Kappagoda, U. W. M. R. S., Othman, H. Z. F., \& Alwis, G. De. (2014). Psychological Capital and Job Performance: The Mediating Role of Work Attitudes. Journal of Human Resource and Sustainability Studies. https://doi.org/10.4236/jhrss.2014.22009

Kim, T. (Terry), Karatepe, O. M., Lee, G., Lee, S., Hur, K., \& Xijing, C. (2017). Does hotel employees' quality of work life mediate the effect of psychological capital on job outcomes? International Journal of Contemporary Hospitality Management, 29(6), 1638-1657. https://doi.org/10.1108/IJCHM-04-2016-0224

Luthans, F. (2002). The need for and meaning of positive organizational behavior. Journal of Organizational Behavior. https://doi.org/10.1002/job.165

Luthans, F., Avolio, B. J., Avey, J. B., \& Norman, S. M. (2007). Positive psychological capital: Measurement and relationship with performance and satisfaction. In Personnel Psychology. https://doi.org/10.1111/j.1744-6570.2007.00083.x

Luthans, F., Luthans, K. W., \& Luthans, B. C. (2004). Positive psychological capital: Beyond human and social capital. Business Horizons. https://doi.org/10.1016/j.bushor.2003.11.007

Luthans, F., \& Youssef, C. M. (2004). Human, social, and now positive psychological capital management: Investing in people for competitive advantage. Organizational Dynamics, 33(2), 143-160. https://doi.org/10.1016/j.orgdyn.2004.01.003

Luthans, F., \& Youssef, C. M. (2007). Emerging positive organizational behavior. In Journal of Management. https://doi.org/10.1177/0149206307300814

Maddi, S. R. (2005). Hardiness as the key to resilience under stress. Psychology Review, 11(1), 20-23. Maher, A., Mahmoud, H. S., \& Hefny, S. El. (2017). Authentic Leadership and Psychological Capital: The Impact on Egyptian Employees' Work Well Being. The Electronic Journal of Knowledge Management, 15.

Masten, A. S., \& Reed, M.-G. J. (2002). Resilience in development. Handbook of Positive Psychology, $74,88$.

Meyers, L. S., Gamst, G., \& Guarino, A. J. (2006). Applied multivariate research: Design and interpretation. In Book. https://doi.org/10.1057/jors.1994.29

Nasurdin, M. A., Ling, C. T., \& Khan, N. S. (2018). The Role Of Psychological Capital On Nursing Performance In The Context Of Medical Tourism In Malaysia. In International Journal of Business and Society (Vol. 19, Issue 3).

Motowidlo, S. J., Borman, W. C., \& Schmit, M. J. (1997). A theory of individual differences in task and contextual performance. Human Performance. https://doi.org/10.1207/s15327043hup1002_1

Murphy, K. R. (1989). Dimensions of job performance. Testing: Theoretical and Applied Perspectives. Pallant, J. (2011). A step by step guide to data analysis using SPSS. Alen \& Unwin.

Peterson, S. J., \& Byron, K. (2008). Exploring the role of hope in job performance: Results from four studies. Journal of Organizational Behavior. https://doi.org/10.1002/job.492

Peterson, S. J., Luthans, F., Avolio, B. J., Walumbwa, F. O., \& Zhang, Z. (2011). Psychological Capital And Employee Performance: A Latent Growth Modeling Approach. In Personnel Psychology (Vol. 64). 
INTERNATIONAL JOURNAL OF ACADEMIC RESEARCH IN BUSINESS AND SOCIAL SCIENCES Vol. 10, No. 8, 2020, E-ISSN: 2222-6990 @ 2020 HRMARS

Polatci, S., \& Akdogan, A. (2014). Psychological capital and performance: the mediating role of work family spillover and psychological well-being. Business and Economics Research Journal, 5(1), 1.

Ramphal, R. R. (2016). A Complaints Handling System for the Hospitality Industry. African Journal of Hospitality, Tourism and Leisure.

Roodt, G., \& La Grange, L. (2001). Personality and cognitive ability as predictors of the job performance of insurance sales people. SA Journal of Industrial Psychology, 27(3), 35-43.

Saithong-in, S., \& Ussahawanitchakit, P. (2016). Psychological capital and job performance: an empirical research of certified public accountants (CPAs) in Thailand. The Business \& Management Review, 7(5), 499.

Santos, A. S., Reis Neto, M. T., \& Verwaal, E. (2018). Does cultural capital matter for individual job performance? A large-scale survey of the impact of cultural, social and psychological capital on individual performance in Brazil. International Journal of Productivity and Performance Management, 67(8), 1352-1370. https://doi.org/10.1108/IJPPM-05-2017-0110

Sheldon, K. M., \& King, L. (2001). Why positive psychology is necessary. American Psychologist. https://doi.org/10.1037/0003-066X.56.3.216

Snyder, C. R. (2000). Handbook of hope: Theory, measures, and applications. In Handbook of hope: Theory, measures, and applications. https://doi.org/99-68018

Snyder, C. R., Harris, C., Anderson, J. R., Holleran, S. A., Irving, L. M., Sigmon, S. T., Yoshinobu, L., Gibb, J., Langelle, C., \& Harney, P. (1991). The Will and the Ways: Development and Validation of an Individual-Differences Measure of Hope. Journal of Personality and Social Psychology. https://doi.org/10.1037/0022-3514.60.4.570

Snyder, C. R., Sympson, S. C., Ybasco, F. C., Borders, T. F., Babyak, M. A., \& Higgins, R. L. (1996). Development and Validation of the State Hope Scale. Journal of Personality and Social Psychology. https://doi.org/10.1037/0022-3514.70.2.321

Stajkovic, A. D., \& Luthans, F. (1998). Social cognitive theory and self-efficacy: Goin beyond traditional motivational and behavioral approaches. Organizational Dynamics. https://doi.org/10.1016/s0090-2616(98)90006-7

Tiger, L. (1979). Optimism: The biology of hope.

Tüzün, I. K., Çetin, F., \& Basim, H. N. (2018). Improving job performance through identification and psychological capital. International Journal of Productivity and Performance Management. https://doi.org/10.1108/IJPPM-03-2016-0060

Khan, U. S., Saeed, I., Qadir, G., \& Khattak, Q. (2017). Effect of Psychological Capital and Emotional Intelligence on Employee's Job Performance. In Journal of Business and Tourism: Vol. July - Dec. https://www.researchgate.net/publication/323018179

Sekaran, U., \& Bougie. (2013). Research Method for Business: A skill Building Approach, 6th edition.Wiley\&Son Ltd. In United States: John Wiley \& Sons Inc.

Wright, T. A., \& Hobfoll, S. E. (2004). Commitment, psychological well-being and job performance: An examination of conservation of resources (COR) theory and job burnout. In Journal of Business \& Management. https://doi.org/Article

Youssef-Morgan, C. M., \& Luthans, F. (2015). Psychological capital and well-being. In Stress and Health. https://doi.org/10.1002/smi.2623. 